Jan Bulak

Uniwersytet Papieski Jana Pawła II w Krakowie

\title{
Między panem wójtem i plebanem... Konflikt wójtowsko-plebański w latach 6o. i 7o. XIX wieku w podkrakowskiej wsi
}

Przyjazna koegzystencja ośrodków władzy duchowej i świeckiej mogła (i nadal może) przynieść każdej społeczności liczne korzyści. Na przestrzeni dziejów kooperacja plebanii i dworu wymagała jednak wielu umiejętności dyplomatycznych i dobrej woli - wówczas owocowała nowymi inwestycjami w parafii czy współpracą w samorządach. Mimo to relacje między dwoma wspomnianymi ośrodkami nie wszędzie układały się idealnie.

W XIX wieku podkrakowska parafia Zielonki liczyła już sześć wieków - pierwsza historyczna wzmianka o wsi pochodzi bowiem z 1260 roku¹. Do 1531 roku zwierzchnictwo nad parafią sprawowała krakowska kapituła katedralna, zaś po tej dacie dziekani tamtejszej kolegiaty św. Anny, przy czym prawo prezenty należało do senatu Uniwersytetu Krakowskiego ${ }^{2}$. Proboszczami zostawali najczęściej stale przebywający w Krakowie profesorowie Kolegium Większego, natomiast w Zielonkach pracowali wikariusze, zamieszkujący plebanię przy kościele ${ }^{3}$.

1. Monumenta Poloniae Historica, t. 2, opr. A. Bielowski, Lwów 1872, s. 807, rok 1260.

2. K. Morawski, Historia Uniwersytetu Jagiellońskiego. Średnie wieki i odrodzenie, t. 2, Kraków 1900, s. 280. J. Urban nazywa wręcz kościół zielonecki filią kolegiaty św. Anny (J. Urban, Diecezja krakowska w XIX w., w: Kościół krakowski w tysiącleciu, Kraków 2000, s. 352).

3. J. Bulak, Duchowieństwo parafii Zielonki (1795-1918), w: XLV Międzynarodowe Seminarium Kół Naukowych "Koła Naukowe - Szkoła Twórczego Działania”, t. 1, red. M. Gryglik i in., Olsztyn 2016, s. 47, https://msknolsztyn.files.wordpress. 
W okresie przedrozbiorowym wieś dzieliła się na dwie części: pierwsza należała do kapituły (nazywana Kapitułką), zaś druga była własnością królewską ${ }^{4}$. Po 1795 roku Zielonki znalazły się w granicach zaboru austriackiego i pozostawały w nich do 1809 roku. Następnie weszły w skład Księstwa Warszawskiego. W 1815 roku, po upadku Księstwa, część parafii znalazła się na terenie Rzeczypospolitej Krakowskiej, a po wkroczeniu wojsk zaborczych w 1846 roku parafia leżała w zaborze austriackim do 1918 roku. Od 1809 roku Zielonki podlegały duchownemu zwierzchnictwu dziekana bolechowickiego. Przed utworzeniem systemu powszechnego szkolnictwa ośrodki inteligencji na terenie parafii stanowiły plebania i okoliczne dwory: na Marszowcu (część Zielonek), w Toniach, Pękowicach, Witkowicach, Górce Narodowej i Garlicy Murowanej5. Rodziny ziemiańskie wspomagały kościół parafialny zarówno materialnie, przekazując bogate dary lub łożąc pieniądze na bieżące potrzeby ${ }^{6}$, jak i niematerialnie, na przykład poprzez porady lub zasiadanie w komitecie parafialnym ${ }^{7}$.

W niniejszym artykule zostanie podjęty temat tylko jednego, krótkiego okresu w dziejach parafii, w którym nie było współdziałania między tymi ośrodkami. Skupimy się na antagonizmach między wikarymi a wiernymi, ze szczególnym uwzględnieniem marszowieckiego dworu Ślizowskich. Temat ten nie został dotąd podjęty przez żadnego badacza. Trudno też znaleźć opracowanie dotyczące analogicznych sporów w innych parafiach. Źródłem stanowiącym podstawę niniejszego opracowania są akta parafialne Zielonek, przechowywane w Archiwum Kurii Metropolitalnej w Krakowie [dalej: AKMKr, APA] ${ }^{8}$. Nie zachowały się niestety akta personalne księży będących bohaterami opisywanych wydarzeń. Nie

com/2016/og/tom-1-sekcja-humanistyczna-sekcja-teologiczno-kanonistyczno-familiologiczna.pdf (dostęp: 20.03.2017).

4. $\quad$ M. Wyżga, W tej pięknej ziemi. Gmina Zielonki od średniowiecza do czasów współczesnych, Zielonki 2009, s. 37-38.

5. W Bibicach, kolejnej wsi należącej wówczas do tej parafii, znajdował się folwark norbertanek zwierzynieckich, którego mieszkańcy (dzierżawcy) sporadycznie włączali się w funkcjonowanie parafii. Zob. W. Urban, Wieś podkrakowska w dobie nowożytnej. (Dzieje Bibic w latach 1475-1918), Kielce-Kraków 1976, passim.

6. Przykładem mogą być zapiski dotyczące składek na cele parafialne, np. Archiwum Parafii Zielonki [dalej: APZ], Księga zawierająca spis sprawionych rzeczy do kościoła w wsi Zielonki oraz nakłady wyłożone na reparacją budynków plebańskich, s. $3,4,10$.

7. APZ, Kronika parafialna, t. 1, s. 16.

8. Aby poprawić czytelność często cytowanych w tej pracy pism, dokonano modernizacji pisowni. 
odnaleziono także archiwaliów dworu marszowieckiego, które mogłyby rzucić inne światło na ówczesny konflikt dworsko-plebański.

Cezury czasowe wyznacza posługa duszpasterska w Zielonkach dwóch wikarych: Adama Kwiatkowskiego (1862-1867) oraz Wojciecha Knapczyka (1867-1873). Obaj cechowali się uporem i konfliktowym charakterem, co niewątpliwie mogło przyczynić się do tego, iż nigdy nie zostali proboszczami. Pierwszy z nich w chwili przyjścia do Zielonek miał 52 lata (ur. 1810). Dwukrotnie studiował w seminarium krakowskim, najpierw w roku akademickim 1835/1836, by powrócić tam po 11 latach i zostać wyświęconym w 1850 roku. Parafia Zielonki była jego czwartym wikariatem ${ }^{9}$. Odszedł stamtąd w roku 1868, po czym pełnił funkcję penitencjarza kościoła Mariackiego, a następnie przeszedł w stan spoczynku i mieszkał w domu księży emerytów do swojej śmierci w 1888 roku $^{10}$.

Wojciech Knapczyk w chwili rozpoczęcia posługi w Zielonkach również miał 52 lata (ur. 1815). Studiował filozofię we Lwowie, teologię w Krakowie oraz zaliczył jeden semestr na Wydziale Lekarskim UJ, po czym wstąpił do seminarium duchownego w Krakowie, które zakończył prezbiteratem w 1854 roku $^{11}$. Dwa lata później z powodu konfliktu ze swoim przełożonym, proboszczem w Morawicy ${ }^{12}$, został skierowany przez władze duchowne do zakładu poprawczego dla księży w Przeworsku (1856-1857) ${ }^{13}$, co przypłacił utratą zdrowia. Prawdopodobnie już wówczas był skonfliktowany z wieloma środowiskami ${ }^{14}$. Zielonki były jego szóstym wikariatem. Po odejściu

9. Elenchus Venerabilis Cleri tam Saecularis quam Regularis Partis Dioecesis Cracoviensis Imperio Caesareo-Austriaco in Civilibus Subjectae et Scholarum in Eadem Existentium Anno Salutis [i in. dalej: Elenchus... Kraków] (1839-1888); J. Szczepaniak, M. Hałaburda, Katalog alumnów seminarium na Stradomiu (1801-19oo), Kraków 2006, s. 136.

10. Elenchus... Kraków (1867-1888).

11. Elenchus... Kraków (1852-1873, 1874), s. 65; J. Szczepaniak, M. Hałaburda, Katalog alumnów..., dz. cyt., Kraków 2006, s. 113; Corpus studiosorum Universitatis Iagellonicae 1850/51-1917/18, t. 3, red. K. Stopka, aut.: M. Barcik, A. Cieślak, D. Grodowska-Kulińska, U. Perkowska, M. Żukowski, Kraków 2009, s. 272.

12. Zob. AKMKr, APA 204, k. 477-479, 481-482; APA 355, k. 241-242, 264.

13. Zakłady odosobnienia dla księży mieściły się wówczas na podkrakowskich Bielanach oraz właśnie w Przeworsku, w pobernardyńskim klasztorze (J. Urban, Diecezja krakowska..., dz. cyt., s. 351). Ks. Knapczyk pełnił sprawował tam posługę tylko przez pół roku (AKMKr, Wizytacje dziekańskie dekanatu Bolechowice z 1867 r.).

14. W aktach konsystorza krakowskiego ks. Knapczyk poruszył ten wątek tylko raz, w skardze z 6 II 1872 adresowanej do ks. Jana Chełmeckiego, który również przebywał w Przeworsku: „[...] na ukojenie ran, które mi władza diecezjalna bez najmniejszej winy zadała przez pogwałcenie w Przeworsku więzieniem mego zdrowia, 
z Zielonek (czerwiec 1873) zamieszkał w Półwsiu Zwierzynieckim pod Krakowem, gdzie zmarł cztery miesiące później, 15 października ${ }^{15}$.

Rodzina Ślizowskich była szczególnie aktywna w społeczności Zielonek. Zamieszkiwała, jak wspomniano, dwór na Marszowcu i dzierżawiła od proboszczów prawo propinacji. Wspomniany w tej pracy przedstawiciel rodziny Kamil Ślizowski urodził się w 1824 roku jako syn Pawła i Tekli z Bieleckich. Wiadomo, iż przed 1862 rokiem ożenił się z Walerią Bielecką. Z tego małżeństwa przyszło na świat trzech synów: Bolesław, Walery i Władysław. Mateusz Wyżga podaje, iż Kamil prawdopodobnie uczestniczył w powstaniu styczniowym, gdzie uzyskał stopień majora wojsk powstańczych. Bardziej prawdopodobne jest, iż w Zielonkach - nieobjętych działaniami insurgentów - organizował pomoc dla powstańców, współpracując w tym celu z późniejszym wójtem Zielonek Janem Majdrą. Po upadku powstania Ślizowski pełnił funkcję wójta oraz był członkiem komitetu parafialnego, z czego zrezygnował wskutek sporów z zieloneckimi wikariuszami. Zmarł 7 sierpnia 1874 roku $^{16}$.

\section{Geneza konfliktu między parafianami zieloneckimi a wikariuszami}

Najczęstszą przyczyną sporu pomiędzy księżmi a kolatorami (miejscowymi właścicielami ziemskimi) było zaniedbywanie obowiązków kapłańskich lub ich złe wykonywanie. Nie bez znaczenia pozostawały także sprawy finansowe czy urażone ambicje którejś ze stron. Zielonecka parafia, której proboszczowie rezydowali w Krakowie, była w XIX wieku traktowana wyłącznie jako źródło dochodów. Jeszcze przed omawianym okresem, 17 grudnia 1861 roku, Ślizowski i Jan Orzechowski (członek komitetu kościelnego, późniejszy wójt Zielonek) wystosowali pismo do konsystorza krakowskie$\mathrm{go}^{17}$, żaląc się na coraz gorszy stan kościoła i plebanii. Jednocześnie prosili "o poczynienie kroków, by zapobiec upadkowi"18. List ten został skierowany do C.k. władzy obwodowej, czyli świeckiej¹. Kolejny przykład zaniedbań

którego mi już nigdy nie jest w stanie wrócić..." (AKMKr, APA 355, k. 264); zob. K. Kamieński, "Okropne dzieje przyniósł nam czas". Duchowieństwo diecezji tarnowskiej wobec wydarzeń 1846 roku, Tarnów 2015, s. 40, 87, 92, 93, 99, 100, 102, 137.

15. AKMKr, APA 355, k. 296, 378.

16. M. Wyżga, W tej pięknej ziemi..., dz. cyt., s. 120; W. Gwizdała, Nad Białucha, dz. cyt., 1983, s. 15-24 [maszynopis w posiadaniu Biblioteki Publicznej w Zielonkach].

17. Tak w tej pracy (za dziewietnastowiecznymi źródłami) określamy kurię biskupią.

18. AKMKr, APA 355, k. 88.

19. AKMKr, APA 355, k. 89, Protokół czynności Konsystorza Illnego z roku 1861, nr 1873. 
to nieprowadzenie metryk urodzin i zgonów w latach 1856-1862 przez ks. Kajetana Kulpińskiego, poprzednika ks. Kwiatkowskiego. Duchowny ten zabrał nawet akta parafialne z Zielonek do kolejnej parafii. Po skardze swego następcy ks. Kulpiński otrzymał naganę oraz wezwanie do uporządkowania ksiąg, przy czym określono, iż winne było jego "próżniactwo"20.

Pretensje spowodowane niektórymi decyzjami zieloneckich wikarych zgłaszali także wierni niższego pochodzenia. Spory parafian z księżmi dotyczyły głównie sprawowania sakramentów. Wikariusze niejednokrotnie wstrzymywali śluby, jeśli dopatrzyli się niedopełnienia formalności. Przykładowo, 8 sierpnia 1864 roku Karol Bochymski, C.k. nadstrażnik finansowy, złożył zażalenie na ks. Kwiatkowskiego, gdy ten w lipcu odmówił jego córce ${ }^{21}$ wydania niezbędnej do zawarcia małżeństwa metryki chrztu ${ }^{22}$. Ks. Kwiatkowski tłumaczył później²3 iż chciał wydać takie zaświadczenie, jednak list nadstrażnika z 2 złotymi reńskimi opłaty zaginął na poczcie. Powtórny list został dostarczony mu dopiero 7 sierpnia, jednak nie zawierał stempla ani opłaty, więc nie mógł wydać odpisu. Wikariusz zielonecki wydał odpis metryki dopiero po nakazie konsystorza, co kosztowało Bochymskiego 6 złr. Na tę sumę złożyła się należność za transport furmanką do konsystorza oraz 2 złr opłaty manipulacyjnej, które Kwiatkowski przeznaczył na fundusz dla krakowskich pogorzelców ${ }^{24}$. Podobne sprawy występowały w parafii w interesującym nas okresie jeszcze kilkukrotnie. W 1866 roku Rozalia Zasada poprosiła o wstrzymanie ślubu Tomasza Ciupki, jej byłego narzeczonego, ponieważ ten obiecywał, że się z nią ożeni ${ }^{25}$. W 1869 roku wójt Ślizowski wniósł skargę do starostwa powiatowego z powodu podejrzenia bezprawnego błogosławieństwa ślubu Urszuli Lipiarzównej; zbadanie tej sprawy zostało powierzone dziekanowi bolechowickiemu ${ }^{26}$. Wreszcie w 1870 roku, ks. Knapczyk został oskarżony przez Wojciecha Kuta o uniemożliwianie zawarcia małżeństwa. Znów na drodze do ożenku stanęła inna

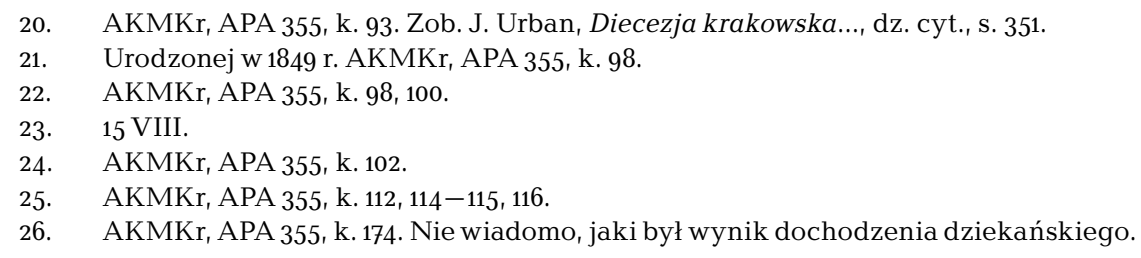


kobieta, jednak po wymianie pism między Kutem, konsystorzem i kapłanem władza duchowna zgodziła się na ten sakrament ${ }^{27}$.

Nie dziwi, iż sprawy pieniężne również były przyczyną konfliktów w parafii. W 1868 roku starszy działającego w parafii bractwa św. Anny Tomasz Nakielski zabrał korale, które zmarła Marianna Majkowa ofiarowała na obraz św. Anny, i zastawił je w banku pobożnym. Najwidoczniej zrobił to bezprawnie, skoro została wysłana w tej sprawie skarga do konsystorza, przekazana następnie sądowi miejskiemu ${ }^{28}$. Jeszcze w tym samym roku spisano nowy inwentarz parafii ${ }^{29}$. W 1871 roku wybuchł konflikt dotyczący pobierania przez ks. Knapczyka pieniędzy z pokładnego, w którym stroną oskarżającą był dziedzic Pękowic i członek komitetu kościelnego Hipolit Wydrychiewicz $^{30}$. W 1872 roku zarzucał on również, iż wikariusz zielonecki przetrzymuje 275 fl z datków na ozłocenie ołtarza ${ }^{31}$. Po dłuższej wymianie pism - w której dziedzic Pękowic był oskarżany przez oponenta o „dopuszczenie się grubego kłamstwa"32 - 26 marca 1872 roku konsystorz wydał komunikat, iż ks. Knapczyk bezprawnie użył pieniędzy komitetu parafialnego ${ }^{33}$.

Dziedzic Pękowic mocno angażował się w życie parafialne. To za sprawą jego determinacji powstały w Zielonkach nowe stodoła i stajnia, na budowę których konsystorz wydał pozwolenie 19 kwietnia 1872 roku $^{34}$. Inwestycja była konieczna, ponieważ, jak relacjonował nowo przybyły do parafii ks. Knapczyk,

[...] stajnie, obory i chlewy już runęły, na stodole zaś szczyt zupełnie zarwany siłą wiatru i pierwsza jakakolwiek burza, gdy kiedy nadejdzie, toto dość piękne i kosztowne zabudowanie wywróci, które by teraz jeszcze na czasie niewielkim kosztem można ochronić od ruiny... ${ }^{35}$

27. AKMKr, APA 355, k. 181, 183-184, 185, 187-188, 189, 191-192, 196, 197. 19 II 1870 ks. Sosnowski wystosował do konsystorza pismo, w którym umieścił następujące ważne zdanie: "[...] Że [...] zaś ksiądz Knapczyk poważył z nieuszanowaniem Wysokiej Władzy takową w błąd wprowadzić, to jest zastanowienia i skarżenia godne..." (k. 196v).

28. AKMKr, APA 355, k. 146, 148.

29. AKMKr, APA 355, k. 150.

30. AKMKr, APA 355, k. 250, 251, 254, 260, 262, 274, 276-277, 278, 326.

31. AKMKr, APA 355, k. 260.

32. AKMKr, APA 355, k. 276.

33. AKMKr, APA 355, k. 270.

34. AKMKr, APA 355, k. 313.

35. AKMKr, APA 355, k. 151v. Inne pisma na temat budowy: AKMKr, APA 355, k. 281, $320,306,313$ 
Brak bezpośredniego dozoru proboszczów i powierzenie beneficjum zieloneckiego wikariuszom prowadziło też do konfliktów między samymi księżmi. Analizowane akta parafialne są pełne skarg jednej i drugiej strony. W niniejszej pracy temat ten zostanie jedynie zarysowany. W większości spory między kapłanami miały podłoże finansowe, gdyż nie było jednolitej regulacji wielkości dochodu wikariuszy, co powodowało niezadowolenie księży.

\section{Instancje rozstrzygające spory dworsko-plebańskie}

Istotę sporów między dziedzicem dworu marszowieckiego a wikarymi zieloneckimi stanowiło ich złe oddziaływanie na parafian. Było ono zaś tym większe i bardziej gorszące, im o więcej instancji się opierało. Podobnie działo się, gdy konflikt zaistniał między dwoma księżmi. We wszystkich sprawach należy wyróżnić trzy instytucje odwoławcze: proboszcza jako nadrzędną jednostkę dla wikariusza (gdzie proboszcz odpowiadał przed konsystorzem); instytucje świeckie, wiążące dla wójta Zielonek i rozstrzygające regulowane ustawami sprawy finansowe czy majątkowe; wreszcie opinię lokalną, z którą musiały się liczyć obie strony sporu.

Sytuacja władzy duchownej w tym okresie nie była łatwa. Diecezja formalnie nie istniała, a rezydujący w Krakowie biskupi byli jedynie administratorami apostolskimi. Okres zawieszenia rozpoczął się w 1851 roku (kiedy po śmierci przebywającego na wygnaniu bpa Karola Skórkowskiego nie powołano nowego biskupa krakowskiego) i trwał do roku $1879^{36}$. Powodem tego były niesnaski między Austrią a Rosją dotyczące części diecezji wchłoniętej do zaboru rosyjskiego po 1815 roku. Taką funkcję administratora (wikariusza apostolskiego) w omawianym przedziale czasowym pełnił biskup tytularny Antoni Junosza Gałecki (1862-1879), znany w diecezji jako zwolennik polityki proaustriackiej. Do niego więc kierowano wszelkie pisma: skarżyli się doń zarówno Kamil Ślizowski oraz Hipolit Wydrychiewicz, jak i podlegli administratorowi księża Kwiatkowski i Knapczyk. Biskup Gałecki wiedział o tym, co dzieje się w parafii, jednak - jak wynika z analizowanych źródeł - nie podjął zdecydowanych kroków. Opieszałość konsystorza wytknął ks. Knapczyk, gdy miesiąc przed swoją śmiercią prowadził spór dotyczący żądania wypłacenia mu

36. Zob. B. Kumor, Ustrój i organizacja Kościoła polskiego w okresie niewoli narodowej (1772-1918), Kraków 1980, s. 170-174; J. Urban, Diecezja krakowska..., dz. cyt., s. $354-360$. 
pieniędzy przez administratora kolegiaty św. Anny. 6 września 1873 roku wymawiał władzy duchownej, że żadna sprawa nie była załatwiana „jak należy", a na pisma próbujące łagodzić spór odpowiadał nie bez słuszności: „[...] Konsystorz zaleca cierpliwość, wszakże obok cierpliwości trzeba się koniecznie czemś pożywiać..."37 W sytuacjach bardziej zawiłych władza administratury rozwiązywała sprawę poprzez dziekanów, którzy przeprowadzali dochodzenie, spisywali zeznania obu stron sporu oraz wydawali opinię. Ostateczną decyzję podejmował biskup administrator. W sytuacji wniesienia skargi do konsystorza z pominięciem proboszcza, władza duchowna przesyłała pismo do plebana, aby się z nim zapoznał i zbadał zarzuty ${ }^{38}$. Podobną procedurę kierowania dokumentów stosowano wobec dziekana bolechowickiego. Przykładowo, po przesłaniu przez ks. Knapczyka 20 kwietnia 1869 roku pisma do konsystorza, w którym informował o niemożności przystąpienia do egzaminu beneficjalnego, władza duchowna przekazała pismo dziekanowi, który zbadał prawdziwość tego usprawiedliwienia ${ }^{39}$. Decydujące zdaje się być pismo z 13 stycznia 1868 roku, w którym konsystorz prosił księdza Knapczyka, by wszystkie relacje, prośby i pisma urzędowe wnosił „[...] za pośrednictwem WJX Sosnowskiego [...] proboszcza swego, celem by tenże wiedział o tem wszystkiem, co w parafii jego się dzieje" $\mathrm{e}^{\prime \prime}$.

C.k. krakowski urząd powiatowy również pełnił funkcję instytucji rozstrzygającej. Często był pośrednikiem między parafianami a władzą duchowną. Przykładem tego jest zapis z roku 1867, gdy urząd zwrócił się do konsystorza z prośbą o nadzór budowy kostnicy w Zielonkach, gdyż członkowie komitetu kościelnego nie ufali swoim wikariuszom ${ }^{41}$.

Instancją wyższą niż starostwo było lwowskie namiestnictwo. W 1869 roku tamtejszy radca wydał odezwę do konsystorza, w której zwracał uwagę na trudności z wykonaniem ustawy z 2 lutego 1867 roku o utworzeniu funduszów parafialnych. Ślizowski bezskutecznie wzywał ks. Knapczyka do wypłacenia należnej kwoty swoim dwóm służącym. Poinformował więc władzę duchowną, iż

\footnotetext{
37. AKMKr, APA 355, k. 367.

38. Zob. AKMKr, APA 355, k. 122.

39. AKMKr, APA 355, k. 163, 164, 169, 171, 172 i in.

40. AKMKr, APA 355, k. 146.

41. AKMKr, APA 355, k. 136.
} 
Bezskuteczność tych wezwań upoważnia wprawdzie Naczelnika Gminy [Ślizowskiego - JB] do kroków przymusowych, lecz zamiast tego udał się powołanym raportem do mnie [Radcy Namiestnika - JB], przedstawiając, że użycie tego prawa egzekucji wywołałaby - wobec znanego naprężenia stosunków jego z rzeczonym kapłanem - następstwa, które by do istniejącego zgorszenia dodały nowe... ${ }^{42}$

Prosił też konsystorz o wpłynięcie na wikarego, aby ten „nie dawał przykładu wyłamywania się spod obowiązujących ustaw"43. W opisywanych sprawach zabierała również głos Ekspozytura C.k. Prokuratorii Skarbu ${ }^{44}$ oraz Sąd Krajowy ${ }^{45}$.

Nie mniej istotna była opinia publiczna, czyli parafianie - widzowie sporów między wikarymi a Ślizowskim. Mieszkańcy wsi często występowali jako świadkowie w dochodzeniach, stając się mimowolnie przedmiotem ataków przeciwnej strony ${ }^{46}$. Bardzo często obie strony sporu, a także władza duchowna, traktowały opinię publiczną jako środek do otrzymania zadośćuczynienia. Zniecierpliwiony opieszałością konsystorza dziedzic Marszowca pisał wprost o swoich zamiarach biskupowi Gałeckiemu: "[...] gdybym bowiem tego od Waszej Ekscelencji nie uzyskał, to najprzód oddam ks. Knapczyka pod sąd opinii publicznej, a potem postawię go przed kratki sądu karnego..."47. Konflikt wywołany usilnymi próbami zmiany ówczesnej sytuacji w parafii przez wpływanie na postawę wikarego z pewnością był przyczyną zgorszenia maluczkich. Strony doskonale

42. AKMKr, APA 355, k. 176.

43. AKMKr, APA 355, k. 176. Tydzień później konsystorz wezwał ks. Knapczyka do zapłaty, bowiem „[...] powinien dawać parafianom i w tym względzie dobry przykład i ponieważ tak bagatelna kwota nie warta, aby ściągnienie jej władze zatrudniało i niepotrzebnie czas im zabierało..." (AKMKr, APA 355, k. 177). Zob. AKMKr, APA $355, \mathrm{k} .326$.

44. AKMKr, APA 355, k. 324 .

45. AKMKr, APA 355, k. 241.

46. Na przykład 4 VII 1872, kiedy ks. Knapczyk zawarł opinię o świadkach sporu gruntowego ze Ślizowskim w piśmie do konsystorza: „[...] Ze strony zaś interesujących są następujący: Jan Maycherek, który podczas komisji nie mógł językiem władać dobrze, będąc pijanym, Jan Pietrzyk, Piotr Krawczyk, Michał Krawczyk nałogowi pijacy, Szczepan Nowak, na których się C.k. Expozytura Prokuratorii na podstawie sprawozdania p. Komisarza powołuje. Takich to świadków użył p. Komisarz, aby tylko całą sprawę paraliżować i wikłać..." (AKMKr, APA 355, k. 316v).

47. AKMKr, APA 355, k. 242. 
zdawały sobie z tego sprawę, skoro używano tego argumentu przeciw antagoniście ${ }^{48}$.

\section{Spory pomiędzy Kamilem Ślizowskim a wikariuszami w Zielonkach}

\section{Ślizowski-Kwiatkowski}

Ks. Adam Kwiatkowski prawdopodobnie traktował parafię w Zielonkach jako miejsce, z którego przejdzie na stanowisko proboszcza. Już wcześniej, w 1858 roku, zdał egzamin na proboszcza z wynikiem dobrym, jednak porywczy charakter uniemożliwił mu awans w hierarchii kościelnej ${ }^{49}$.

10 maja 1866 roku podczas mszy w zieloneckim kościele, między godziną 11 a 12, poroniła Agata Serczyk. Ks. Kwiatkowski uznał to wydarzenie za podstawę do zamknięcia kościoła i poprosił władzę duchowną o udzielenie pozwolenia na rekoncyliację świątyni. Zgoda została wydana 12 maja ${ }^{50}$, jednak konsystorz zażądał od wikarego informacji, dlaczego zamknął świątynię. Odpowiedź z 24 maja była złożona z dwóch części. Pierwszą było uzasadnienie teologiczne, wzięte z Institutiones theologiae moralis Andrzeja Pohla: „[...] qui in ecclesia polluta celebrat, graviter peccat"51. Jako drugi powód duchowny podał niedostateczną wiedzę na temat okoliczności poronienia, które mogło nastąpić z powodu skrzywdzenia kobiety lub celowego pozbycia się ciąży:

[...] Rozumowania były takie - mówiły - że może ją kto w kościele w bok uderzył albo też może w domu od męża jest zbita, albo też może lekarstwo wypiła takie, przez które nastąpiło poronienie ${ }^{52}$.

W pisemnej prośbie o rekoncyliację, napisanej zaraz po zdarzeniu, nie zawarto jednak powyższej argumentacji, gdyż wynikało to - według relacji ks. Kwiatkowskiego - z pośpiechu oraz szoku Agaty Serczyk („mówić nie mogła"). Zaraz po złożeniu podania do konsystorza wikariusz zielonecki przez 12 dni próbował ustalić przyczynę tragedii. Ostateczne świadectwo

48. AKMKr, APA 355, k. 176, 242, 319 .

49. AKMKr, APA 355, k. 91.

50. Słowo „zgoda” jest cytatem z pisma ks. Kwiatkowskiego z 24 maja. Tymczasem 12 maja konsystorz wyraźnie oponuje jego działaniom: "[...] w przypadku niniejszem [...] nie zachodzi najmniejsza potrzeba reconciliandi eccl[esi]am". AKMKr, APA 355, k. 120.

51. Kto odprawia nabożeństwo w splugawionym kościele, ciężko grzeszy (łac.).

52. AKMKr, APA 355, k. 118. 
złożył Józef Limanowski (rządca Toń). Oznajmił w nim, iż poronienie nastąpiło „[...] tylko z osłabienia sił fizycznych, które z natłoku wielkiego w kościele osłabły siły, tak dalece, że omdlała Agata Serczykowa i wtedy nastąpiło poronienie"53. Konsystorz po tych wyjaśnieniach prawdopodobnie zaniechał wyciągania jakichkolwiek konsekwencji.

Wydarzenie to pozostałoby wyłącznie jednym z wypadków wpisujących się w życie codzienne mieszkańców dziewiętnastowiecznej wsi, gdyby nie stało się pretekstem do postawienia ks. Kwiatkowskiemu innych zarzutów. 5 czerwca 1866 Kamil Ślizowski złożył do konsystorza skargę na swojego wikariusza, jednocześnie prosząc o przeniesienie go do innej parafii ${ }^{54}$. Przesłane uzasadnienie obejmowało jednak nie tylko sprawę zamknięcia kościoła po poronieniu, ale także trzy inne przyczyny, które warto przytoczyć w ich źródłowym brzmieniu:

\section{[...] JX Adam Kwiatkowski:}

Zamknął kościół w Zielonkach od nabożeństwa bez przyczyny, albowiem krew, która była w kościele, była tylko wynikiem z przypadku, a nie ze zbrodni, co pokazuje, że nie zna prawa kościelnego. Wracał juz przyniesionych ciała zmarłych do pochowania do domu, co podpisany kilka razy sam spotkał; a na zapytanie, dlaczego z trupem nazad idziecie, dostał odpowiedź, że nie mamy tyle pieniędzy, co ksiądz żąda.

Z powodu zarzucenia tacy od nabożeństw, pogrzebów itd., zamiast kancelarii urzędnika Stanu Cywilnego to robi targ, a ponieważ wymaga o tej godzinie, np. do ślubu wyznaczonej, aby się stawili, a jakby na kwandrans (!) kto się spóźnił, to nie daje ślubu, a w skutku tego wywoływanie na księdza, obraza, szkandal religijny. Ksiądz wpada w pasję, z kijem goni i bije.

Wznieca nieporozumienie między J[egomością] Księdzem Kanonikiem Sosnowskim proboszczem św. Anny i kościoła w Zielonkach a podpisanym, a to z tego powodu chłop Gwizdała grubarz [grabarz - JB] udziały na gruncie kościelnym podał się do indemnizacji. x. Wikary Kwiatkowski wezwał go, robił z nim komedię, i wmawiał, żeby mu powiedział, czyli go nie podpisany [Ślizowski - JB] namówił do podania się do indemnizacji, co rozniosło się

53. AKMKr, APA 355, k. 118-119.

54. AKMKr, APA 355, k. 122, 124-125. 
nie tylko po całej wsi, ale i po Krakowie, i wójt wsi Zielonek przyszedł do podpisanego i mówił, że słyszał mówiących, że to podpisany miał Gwizdałę namawiać, że ksiądz go wołał i badał na nie podpisany; zawołał do siebie Gwizdałę, któren to samo powtórzył, że x. wikary mówił mu, żeby powiedział, że to podpisany pewnie go namówił, bo skąd by on o tem mógł wiedzieć, gdy taki czyn jest obrazą honoru, dlatego podpisany udaje się z prośbą do Jego Ekscelencji, aby chcąc uniknąć dalszych nieporozumień, przeniósł w miejsce dla niego stosowniejsze x. Kwiatkowskiego a dla parafii Zielonek trochę starszego w rozumie księdza wyznaczył, a to w tem spodziewaniu, że Jego Ekscelencja [A. Gałecki - JB] nie dopuści, aby to na drogę cywilną przeszło.

\section{Z najgłębszem szacunkiem.}

Kamill Ślizowski ${ }^{55}$

Wysuwane przez Ślizowskiego zarzuty wobec ks. Kwiatkowskiego rzucają więcej światła na stosunki między dworem a plebanią oraz na postrzeganie swojej osoby przez dziedzica, który, jak każdy kolator, uważał się za opiekuna słabszych, niemogących się upomniećs6 o swoją krzywdę parafian.

Zarzuty wobec zieloneckiego wikarego były poważne, skoro prośbę o przeniesienie go do innej parafii motywowano jego nieznajomością prawa kościelnego, chciwością, popędliwością, przewrażliwieniem, przemocą i zawziętością. Interesujące jest, iż w opinii Ślizowskiego lepszym kapłanem byłby "starszy w rozumie", a więc mądrzejszy i bardziej doświadczony życiowo. Być może był to przytyk do wieku Kwiatkowskiego, który miał wówczas 56 lat.

Konsystorz skierował pismo dziedzica do proboszcza kościoła św. Anny, Feliksa Sosnowskiego. Ten miał przesłuchać wikariusza i rozstrzygnąć spór. 24 sierpnia (dwa i pół miesiąca później!) ks. Sosnowski przedłożył władzom duchownym raport po rozmowie ze swoim wikariuszem. Sprawa pierwszego zarzutu dotyczącego zamknięcia kościoła została w nim pominięta w wyniku wcześniejszej (nieomawianej szerzej w tej pracy) wymiany listów pomiędzy konsystorzem a ks. Kwiatkowskim. Warto przytoczyć oryginalny tekst raportu:

55. AKMKr, APA 355, k. 124-125.

56. Włościanie nie umieli jeszcze pisać, pierwsza szkoła w Zielonkach powstała bowiem w $1868 \mathrm{r}$. 
Na drugi zarzut względem zwracania ciał zmarłych do domu odrzekł [ks. Kwiatkowski - JB], iż się trafiło dwa lata temu, że przyszła kobieta bez żadnego świadka z dzieckiem zmarłem (niejaka Nowacka) i żądała, żeby go zapisać. Gdy jednakże zapisu bez świadków jako przeciwnego prawu nie mógł przyjąć, a następnie i chować, więc ją odesłał, żeby świadków przyprowadziła, dodając, że już o to samo przez Pana Ślizowskiego w urzędzie powiatowym był skarżonym, że pan naczelnik Steyer uznał słuszność postępowania jego.

Na zarzut trzeci, co do targowania się o nabożeństwa, niedawania ślubów w czasie popołudniowym, jeżeliby tylko kwandrans upłynął, wpadania w pasję i bicia odpowiedział, że co kto ofiaruje, to przyjmuje, a nic więcej nad taksę nie wyciąga, jeżeli kto żąda więcej nabożeństwa albo światła więcej, to i więcej wymaga, co się tyczy ślubów, to przestrzega prawa, by się odbywały z rana, że zaś raz przyszli pijani, to ich do ślubu nie przypuścił, ale ani był, ani z kijem gonił.

Na koniec, co do wzniecania nieporozumień pomiędzy proboszczem miejscowym a JP Ślizowskim, odpowiedział, iż jest to tylko przywidzeniem, nie zaś prawdą.

Z tych danych odpowiedzi wykazuje się najoczywiściej, że nic takiego nie zaszło, za co ksiądz Kwiatkowski mógłby zasługiwać na naganę i życzyć by mu jednak należało roztropności pasterskiej, której mu brakuje, i więcej ogłady, gdyż swoją rubasznością wiele sobie czyni nieprzyjaciół i nie jest lubianym ${ }^{57}$.

Z cytowanego pisma wynika, iż wikariusz Zielonek wszystko uzasadniał przepisami prawnymi, jednak nie miał w sobie cech, które zbliżałyby do niego parafian. Jawił się więc jako człowiek o niemiłej powierzchowności, w którym emocje brały górę nad miłosierdziem. W opinii proboszcza brakowało mu ogłady i roztropności, co przysparzało mu wrogów wśród wiernych. Trzy dni po otrzymaniu tego dokumentu (27 VIII) konsystorz dyplomatycznie załagodził spór, wysyłając pismo do stron ${ }^{58}$, w którym wyłożono ogólną naukę o dobrych i złych zaletach człowieka. List kończył się jednak naganą i pouczeniem ks. Kwiatkowskiego:

57. AKMKr, APA 355, k. 126-127.

58. AKMKr, APA 355, k. 128-129.

Jan Bulak, Między panem wójtem i plebanem... 
[...] okazało się, że x. Kwiatkowski nie ma dość roztropności, jest szorstki i opryskliwy, co od niego odpycha parafian i daje powód do nieporozumień, zwaśń itd. Gdy takie postępowanie do niczego dobrego nie prowadzi, zatem władza diecezjalna widzi się być spowodowana zwrócić uwagę x. Kwiatkowskiego, aby więcej starał się być taktownym w swych czynach, a uprzejmością i grzecznością przyciągał ku sobie serca parafian, w przeciwnym bowiem razie, jako niezdolnego do zarządzania parafią, stamtąd odwołanym by zostal ${ }^{59}$.

Ostatnie słowa należy rozumieć jako zabieg mający z jednej strony zagrozić pozycji wikarego i dać satysfakcję Ślizowskiemu, z drugiej zaś nie przychylić się do prośby dziedzica Marszowca, co powinno zadowolić ks. Kwiatkowskiego. Niewątpliwie jednak mocne słowa konsystorza wywarły presję na zieloneckim wikariuszu, gdyż kilka dni później (2 IX) poprosił o przeniesienie go na wakująca posadę penitencjarza nowej fundacji w kościele Mariackim $^{60}$. Odpowiedź władzy duchownej była negatywna, gdyż stanowisko zostało już przydzielone innemu kapłanowi ${ }^{61}$. Ks. Kwiatkowskiemu udało się zostać penitencjarzem kościoła archiprezbiterialnego dopiero we wrześniu następnego roku ${ }^{62}$; mimo że nie zachowało się żadne pismo z późniejszego okresu, które by to potwierdziło, najprawdopodobniej pozostawił w parafii złą opinię na swój temat ${ }^{63}$.

Ślizowski-Knapczyk

Po odejściu ks. Kwiatkowskiego funkcję wikariusza zieloneckiego przejął ks. Wojciech Knapczyk. Już po zaledwie kilku miesiącach Kamil Ślizowski wystosował do konsystorza pismo, w którym postawił zarzuty nowemu wikaremu. Tekstu nie udało się odnaleźć w aktach parafialnych, zatem nie wiadomo, jakie dokładnie były to uwagi. Z listu ks. Knapczyka (28 III 1868)

59. AKMKr, APA 355, k. 128; por. opinię na temat ks. Knapczyka z akt wizytacji: AKMKr, Wizytacje dziekańskie dekanatu Bolechowice z 1866.

6o. Wakat powstał po objęciu probostwa w Płazie przez ks. Karola Łyżwińskiego. Funkcję tę otrzymał prawdopodobnie ks. Ludwik Machnicki, Elenchus... Kraków (1866-1868).

61. AKMKr, APA 355, k. 130.

62. Kolejny wakat nastąpił po zmianach: ks. Józef Chwastkiewicz został penitencjarzem starej fundacji po ks. Michale Zajączku, który przeszedł do kolegium wikariuszy tegoż kościoła, Elenchus... Kraków (1866-1868).

63. Ks. Knapczyk w jednym z pism podaje jako datę otrzymania pisma przenoszącego go do Zielonek 29 VIII, zaś objęcia funkcji - 20 IX. AKMKr, APA 355, k. 142. 
dowiadujemy się jedynie, iż konsystorz polecił zbadanie prawdziwości oskarżeń specjalnie powołanej komisji. W tym piśmie nadawca nie tylko dziękował władzy duchownej za przychylny dlań list (również nieodnaleziony), ale i skarżył się na swoje warunki pracy. Według jego słów ks. Kwiatkowski pozostawił na plebanii "4 gołe ściany" oraz nie odłożył dla swego następcy "nawet źdźbła słomy". Przy tej okazji ujawniło się również zacięcie ks. Knapczyka, który żalił się na proboszcza Sosnowskiego:

[...] wszystkie potrzeby, jako to opał, wikt itd. kupować, jednem słowem wszystkie dźwigać musi ciężary, nie mając żadnych zasobów i otrzymując tylko 10 złr miesięcznie zamiast 210 złr rocznej przez rząd ${ }^{64}$ wyznaczonej dla wikariuszów pensji od swego proboszcza, domagającego się nadto $2 / 3$ dochodów niestałych, to jest akcydensów, bardzo w Zielonkach rzadko się zdarzających, przy czem puszcza grunt i ogród plebański w dzierżawę, bez których wikariusz wyżyć nie może, musząc co tydzień kosztowne najmować furmanki do Krakowa po żywność. Gdy więc w tak smutnem położeniu podpisany w Zielonkach nadal utrzymać się i długów pozaciąganych spłacić nie jest w stanie, widzi się przeto znaglonym zanieść pokorną prośbę do Prześwietnego Konsystorza o łaskawe uwzględnienie przytoczonych okoliczności i obmyślenie środków utrzymania się w Zielonkach proszącego, który się w opiekę swej Władzy Diecezjalnej oddaje w nadziei pomyślnego skutku ${ }^{65}$.

Ten fragment listu świadczy również o tym, iż często procesujący się ks. Knapczyk znał doskonale procedury rozstrzygania sporów przez władzę kościelną. Potwierdza tę tezę polecenie, które na odwrocie dokumentu skierowano do proboszcza, aby zawarł umowę z wikariuszem ${ }^{66}$. W ten sposób na pewien czas ks. Knapczyk uzyskał płynność finansową.

W kolejnym liście (22 VII 1868) zielonecki wikariusz żali się na układ z proboszczem, który "nie bardzo lubił danego słowa dotrzymać". Został mu obiecany ogród plebański, w którym mógłby uprawiać warzywa: „[...] ziemniaki i inne jarzyny". Mimo danego słowa polecenie wydzierżawienia go chłopu za 15 złr otrzymał Ślizowski (dzierżawca gruntów plebańskich), co

64. Chodzi o reskrypt Ministerstwa Stanu z 23 maja 1861 r. (APZ, Księga wpisywania rozporządzeń władzy duchowej).

65. AKMKr, APA 355, k. 142-143.

66. AKMKr, APA 355, k. 143v, 144. 
uraziło wikarego, który zwrócił należność nowemu dzierżawcy, "aby już żadnego wspólnika nie miał w ogrodzie". Tymczasem pojawił się nowy problem: ks. Sosnowski sprzedał rosnące na drzewach owoce bliżej nieokreślonemu sadownikowi (a nie zostawił ich wikaremu), co przy zbiorze groziło zdeptaniem trawy, którą ks. Knapczyk przeznaczył dla nowo zakupionej krowy $^{67}$. Na kartach korespondencji jeszcze przez długi czas ujawniało się poczucie krzywdy wikarego z powodu braku możliwości uprawy gruntu plebańskiego oraz niesatysfakcjonującej kwoty 210 złr pensji rocznej. Odwlekanie ostatecznego rozstrzygnięcia tej kwestii spowodowane było raczej niechęcią do zażegnania tego sporu zarówno przez władzę duchowną, jak i samego proboszcza ${ }^{68}$.

W rzeczonym liście ks. Knapczyka z 22 lipca nie został podjęty temat relacji z Kamilem Ślizowskim. Wiadomo jednak, iż początkowe skargi dziedzica, a następnie gospodarowanie wbrew zamysłom wikarego i brak szybkiego rozwiązania sprawy mogły przynieść tylko eskalację konfliktu. Niecały miesiąc po opisywanym zażaleniu do konsystorza (18 VIII 1868) Stanisław Bi[e]lecki, ekonom Ślizowskiego (i prawdopodobnie brat jego żony), "zbił x. Wojciecha Knapczyka wikarego z parafii Zielonki, aż przez dni 10 chorował". Mimo niedyspozycji pobity następnego dnia wniósł skargę do konsystorza, a od 20 sierpnia polecenie zastępowania go w obowiązkach na okres choroby otrzymał znany już parafianom ks. Adam Kwiatkowski ${ }^{69}$. Najprawdopodobniej pobicie rzeczywiście było ciężkie, skoro osiem miesięcy później ks. Knapczyk tak uzasadniał niemożność przystąpienia do egzaminu proboszczowskiego:

[...] Resztę zaś chwil najspokojniejszych niby używa podpisany na kurację nadwątlonego zdrowia i domowe zatrudnienie, przy czem doznaje bardzo często wskutek pobicia ciężkiego bólu głowy i przeto nie może się studiom umysł obciążającym zbytnio oddawać, a to tem bardziej, iż mu nawet lekarz to polecił, aby się pracą zbyt wiele wyczerpującą siły umysłowe nie zatrudniał dla uniknięcia następstw szkodliwie na jego zdrowie wpłynąć mogących ${ }^{70}$.

67. AKMKr, APA 355, k. 151-152.

68. Zob. AKMKr, APA 355, k. 153, 157, 161.

69. AKMKr, APA 355, k. 155.

70. AKMKr, APA 355, k. 163. Zob. kk. 164V, 165, 171, 171a. 
Wersję tę potwierdził dzień później dziekan bolechowicki ${ }^{71}$. Spór jednak nie wygasł po tym dramatycznym wydarzeniu. Po dwóch latach (1 IX 1871) Ślizowski złożył zażalenie do administratora diecezji krakowskiej Antoniego Gałeckiego z powodu obrazy jego honoru oraz zażądał satysfakcji od ks. Knapczyka. Zarzuty, które wysuwał właściciel Marszowca, przytaczamy w obszernych fragmentach:

[...] Ksiądz wikary Knapczyk dzierżawi pola, na które włościańskie gęsi weszły, takowe zajął, tj. zafantował, żądał od właściciela zł 15 za gęsi, właściciel przekonany, iż rzeczą niepodobną, aby gęsi w takiej ilości szkodę wyrządziły, a po wtóre, że gęś nie ma tej wartości, więc na to uciążliwe żądanie nie przystał i w tym przedmiocie udał się do mnie, jako do Naczelnika Gminy. Ja napisałem najprzyzwoiciej do ks. Knapczyka, aby poprzednio oszacować szkodę, na co są przysięgli ludzie, a potem drogą właściwą będzie miał tę szkodę powróconą. Ks. Knapczyk na to nie uważał, gęsi nie puścił, pozostawił bez pożywienia i wody, które wskutek tego pozdychały. Takim to sposobem ksiądz Knapczyk naucza religii, wzbudza miłość chrześcijańską i zaufanie do osoby duchownej. Mógłbym tu wiele podobnych czynów przytoczyć. [...] Na owe to pismo moje, które z urzędu mego posłałem, od ks. Knapczyka otrzymałem list, który Waszej Ekscelencji w oryginale przedkładam, którym, jak się Wasza Ekscelencja przekona, jestem obrażony, z którego równie Wasza Ekscelencja nabierze wyobrażenia o charakterze Ks. Knapczyka, a o jego konduicie, usposobieniu umysłowem, to głos ogólny da przekonanie. Prócz tego w sprawie kryminalnej z Panią Walerią Ślizowską w C.k. Sądzie Krajowym karnym wyrokiem z dnia 4 maja 1870 zapadłym przez apelację, zatwierdzonym, uznanym został jako winny zamieszania spokojności publicznej z par. 303 KK. Obecnie podał się ks. wikary Knapczyk do C.k. starostwa w Krakowie o pozwolenie noszenia broni, co jako ks[iędzu] nie tylko nie przystoi, ale nadto złe światło rzuca na podobne czyny i usposobienia.

Z powyższego fragmentu wynika jasno, że musiały istnieć jakieś dokumenty na temat dalszego sporu. Sprawa pobicia ks. Knapczyka ewidentnie

71. AKMKr, APA 355, k. 171.

Jan Bulak, Między panem wójtem i plebanem... 
mocno odbiła się na jego poczuciu bezpieczeństwa, skoro zdecydował się on rozpocząć starania o pozwolenie na broń - to zaś z pewnością zmniejszyło poczucie bezpieczeństwa Ślizowskich. Nie bez znaczenia dla oceny jego charakteru jest również zagłodzenie zwierząt. W kolejnych akapitach dziedzic Marszowca rzuca więcej światła na omawianą we wstępie przeszłość wikarego:

Nadto muszę przedstawić Waszej Ekscellencyi postępowanie ks. wikarego Knapczyka, który ciągle awanturnicze życie pędzi. Tenże ks. Knapczyk był najprzód finanzwachem ${ }^{72}$, następnie udał się do seminarium w Tarnowie, z którego wydalony został, wyświęcony później w Krakowie, za obrazę w kościele w Morawicy z ambony swego bezpośredniego przełożonego został ukarany aresztem przez $2 \frac{1}{2} 2$ roku. Był następnie wikarym w Jaworznie, Trzebini i u P[anny] Maryi w Krakowie, gdzie Jego Ekscelencja od przełożonych konduitę jego zasięgnąć może, przesłany za wikarego do parafii Zielonek na zgromadzeniu dozoru kościelnego tak się nieprzyzwoicie i z ubliżeniem swemu przełożonemu zachował, iż zgromadzeni obywatele dali ks. Sosnowskiemu świadectwo, iż dla utrzymania powagi duchownej dłużej jako ksiądz przy parafii ks. Knapczyk znajdować się nie może. Następnie różne odbył bijatyki i awantury, wywoływania z ambony i szkalowania ludzi po nazwisku i imieniu, w roku bowiem 1870 wziął grunt plebański w dzierżawę, jako w roku interkalarnym, czynszowników zaś, czyli mieszkańców, starostwo pozostawiło przy sobie i zrobiło z nimi umowę. Ks. wikary Knapczyk, nie mając do tychże prawa, w drugie Święto Wielkanocne [tj. Poniedziałek Wielkanocny - JB] zawołał tychże mieszkańców do siebie i kazał tymże pańskie odrabiać, na co, gdy im [tzn. powinnościom pańskim - JB] się sprzeciwili, pobił Jana stolarza przy świadkach Janie Gąsiorze i Marcinie Jezierskim. Drzewo parafialne bez wiedzy i zezwolenia właściciela na swój wyłączny użytek zabrał. Pobił również Jana Muchę z Zielonek przy świadkach, jak poszedł robić zapis dziecka, pobił również przy zapisie dziecka

72. Finanzwache (niem.) - w monarchii austro-węgierskiej uzbrojona i umundurowana celna straż graniczna. 
do chrztu Korzeniowskiego Jakóba z Zielonek przy świadkach. Następnie w dniu 13 sierpnia na polu pobił Franciszka Rożka i jego żonę z Zielonek, i tychże w dniu 15 sierpnia z ambony wywoływał, ubliżając władzy miejscowej. Podmawiał Jana Barana asesora, radnego, aby wójta i swego przełożonego nie słuchał, także ks. Knapczyk zwołuje chłopów na plebanię i tymże hulatyki wyprawia i pijaństwo, w celu przeprowadzenia swych widoków podmawia. Są jeszcze dowody niemoralności i zgorszenia, których tu wstyd wymienić. Te wszystkie fakta może Wasza Ekscelencja sprawdzić kazać ${ }^{73}$.

Te bardzo poważne zarzuty zostały prawdopodobnie odłożone przez konsystorz do rozpatrzenia w przyszłości, gdy obie strony sporu ochłoną. Być może nie dowierzano słowom obrażonego dziedzica Marszowca. Z pewnością natomiast nie przewidziano dramatycznej decyzji Kamila Ślizowskiego o apostazji. W tym celu złożył on 24 listopada 1871 roku pismo do starostwa, wnioskujące o wpisanie go na "listę bezwyznaniowych". W urzędowej odpowiedzi znalazło się pytanie o rzeczywisty status dziedzica, gdyż zapytany ksiądz Chełmecki (administrator po zmarłym proboszczu Sosnowskim ${ }^{74}$ ) twierdził zgoła przeciwnie, jakoby Ślizowski ze swojej decyzji zrezygnował75. Ślizowski uskutecznił jednak swoją decyzję, która mogła być spowodowana nie tylko konfliktem w parafii, ale także całkowitym brakiem zaufania do władzy duchownej. W omawianych latach opinią publiczną wstrząsały wiadomości o sprawie chorej umysłowo siostry Barbary Ubryk (1869), która 21 lat spędziła w bardzo złych warunkach celi klasztoru Karmelitanek Bosych na Wesołej. Ślizowski mógł również nie poważać administratora Gałeckiego, skoro ten zdecydowanie opowiadał się przeciwko powstaniu styczniowemu i kultywowaniu pamięci o nim, a przecież dziedzic Marszowca aktywnie je wspierał ${ }^{76}$.

W sprawie apostazji kolatora administrator parafii odegrał raczej pozytywną rolę (choć sam niedługo potem z powodu braku pokory został

73. AKMKr, APA 355, k. 241-242.

74. Długoletni proboszcz parafii św. Anny i Zielonek zmarł 4 I $1871 \mathrm{r}$.

75. AKMKr, APA 355, k. 249.

76. J. Urban, Diecezja krakowska..., dz. cyt., s. 350-353; J. M. Małecki, W dobie autonomii galicyjskiej (1866-1918), w: Dzieje Krakowa. Kraków w latach 1796-1918, Kraków-Wrocław 1985, s. 250. 
suspendowany przez bpa Gałeckiego ${ }^{77}$ ). Ujawniła się ona w kolejnym liście Ślizowskiego do konsystorza. Zwlekanie przez władzę duchowną z odpowiedzią na podanie o przeniesienie Knapczyka zostało przez dziedzica odczytane jako działanie nieokreślonej osoby w konsystorzu ${ }^{78}$ albo wprost: konsystorz milczał z powodu niedoręczenia pism przez posłańca, czyli właśnie księdza Chełmeckiego ${ }^{79}$. Najprawdopodobniej cel administratora był szczytny - chciał zatrzymać apostazję swojego parafianina i z tego powodu utrzymywał, że Ślizowski zrezygnował ze swojej decyzji. Jednak na niewiele się to zdało, gdyż dziedzic kończył swój list sugestią ukazującą jego desperację: „[...] wstrzymałem się z stanowczem wyrzeknięciem się wiary mych przodków świętej wiary katolickiej [...] upraszam Waszej Ekscelencji o decyzję, od której cała moja nadzieja zależy w pozostaniu nadal w wierze świętej katolickiej a to przez usunięcie x. wik[arego] Knapczyka z parafii w Zielonkach"80. Jego przeciwnik pozostał na swoim stanowisku jeszcze ponad rok, co oddaliło dziedzica Marszowca od Kościoła. Z pewnością udałoby się temu zapobiec, gdyby nie opieszałość krakowskiego konsystorza. Po apostazji Ślizowskiego znów nastąpiła eskalacja konfliktu ${ }^{81}$

77. Ks. Jan Chełmecki około 1873 roku popadł w konflikt z bpem Antonim Gałeckim, za co został przez niego pozbawiony możliwości sprawowania funkcji kapłańskich. Wyrok ten zdjął dopiero papież 19 lipca 1878 r., a konflikt przyczynił się do usunięcia Gałeckiego z administracji krakowskiej. Szerzej na ten temat: M. Łuczewski, Odwieczny naród: Polak i katolik w Żmiącej, Toruń 2012, s. 213.

78. "[...] w samem konsystorzu może się znaleźć osoba, która by udaremniła moje przedstawienie...".

79. " "[...] czyniłem stosowne kroki u Władz Rządowych, jak załączający się dokument Starostwa z dn. 6 stycznia 1872 r. do L. 8062 przekonywa, ale namyśliwszy się, że może moje podanie przez x Chełmeckiego nie zostało jego Ex[celencji] doręczone wraz z dwoma listami pisanemi przez x Knapczyka..." Listy, o których pisał Ślizowski, nie występują wśród badanych akt parafialnych.

80. AKMKr, APA 355, k. 256v-257.

81. Samo wystąpienie Ślizowskiego z Kościoła było również argumentem w późniejszych pismach ks. Knapczyka, w których podważał wiarygodność odstępcy. Jednym z przykładów takiej linii obrony, a zarazem wymownym świadectwem emocjonalności wikarego jest jego list do konsystorza z 4 VII 1872: „[...] Drugim świadkiem był Franciszek Rożek, chciwiec cudzej własności oraz gwałciciel świąt i niedziel, których to świadków popierał silnie wójt gminy Zielonek Kamil Ślizowski, bezwyznaniowy, bez wiary i czci Boga, również gwałciciel świąt i niedziel, a ten osman straszny, gorszyciel parafian, gdyż w roku przeszłym podczas nieszporów nie tylko Franciszek Rożek wiązał w polu zboże i składał go [!] w kopy, ale i wielu innych, idąc za jego przykładem toż samo czynili, bo wójt sam na utwierdzenie bezbożnych w gwałceniu świąt uroczystych i niedziel kazał swym fornalom przecz całe popołudnie w niedziele wozić siano z łąki na wozach właśnie wtedy, kiedy najjaśniejsza była pogoda" (AKMKr, APA 355, k. 316). 
W aktach wizytacji z lat 1867, 1869 i 1872 odnotowano, iż ks. Knapczyk cechował się gorliwością, surowością obyczajów, a jego moralność jest odpowiednią dla stanu duchownego. ${ }^{82} 27$ stycznia 1872 roku konsystorz krakowski otrzymał kolejne zażalenie dziedzica, w którym skarżył się, iż wikariusz zielonecki agituje przeciwko niemu, a więc wójtowi gminy Zielonki, co było nie tylko obrazą osoby, ale i urzędu:

W roku bieżącym, jak i zeszłym x. wikary Knapczyk stara się czy to na ambonie, czy chodząc po domach lub przy pogrzebach swemi mowami uwłaczać władzy miejscowej i powadze urzędu wójta, to mówiąc do ludu, aby nikomu prócz niego nie wierzyli, aby udawali się tym do niego jako do władzy duchownej, to znów "kogóż macie słuchać: czy wójta? czy diabła? czy mnie, waszego kapłana?"83

Podparcie się autorytetem kapłańskim z pewnością było silnym argumentem dla mieszkańców wsi podkrakowskiej, tym bardziej jeśli nazwisko przeciwnika zestawiało się z diabłem (co miało raczej związek z apostazją dziedzica). Działania zieloneckiego wikarego miały więc z pewnością charakter agitacyjny, zmierzający do zapewnienia sobie poparcia parafian w tym sporze. Ślizowski jednak posunął się dalej w swoich oskarżeniach, informując także o hulaszczym trybie życia i używaniu przemocy przez wikarego:

[...] wyprawia bale i narady na plebanii z chłopami przed dwoma tygodniami w kancellaryi urzędu parafialnego Pietrzyka Józefa, któren w interesie żenienia syna swego przyszedł do x. Knapczyka; Orzechowski równocześnie przyprowadził babkę proszalną z Bronowic na oko ślepą (z nazwiska niewiadomą) i kazał x. Knapczykowi bić kijem, co też Knapczyk uskutecznił i pobił Józefa Pietrzyka i ową babkę przy świadkach Józefie Madejskim i jego żonie - wszyscy są z Zielonek ${ }^{84}$.

Po kilku dniach do ks. Knapczyka został wysłany reskrypt administratora parafii ks. Chełmeckiego (niezachowany w aktach parafialnych), na który wikary mu dał pełną rozgoryczenia odpowiedź 6 lutego 1872 roku.

82. AKMKr, Wizytacje dziekańskie dekanatu Bolechowice z l. 1867, 1869, 1872.

83. AKMKr, APA 355, k. 258.

84. AKMKr, APA 355, . 
Prawdopodobnie pismo to zawierało groźbę przeniesienia na inną parafię, jeśli nie nastąpi zmiana obyczajów ks. Knapczyka. Żal z powodu traktowania go w sposób - jego zdaniem - niegodny sprawił, iż posunął się do obrażania na kartach listu swoich parafian, przy czym z pewnością większość inwektyw odnosiła się do dziedzica Marszowca i jego stronników:

Reskrypt Wielmożnego Księdza Administratora [...] zadał mi ciężki cios nie tyle co do ciała, ile co do duszy, jednak zastosuję się do niego z użyciem ostatnich sił moich, opuszczając Zielonki bez woli i wiedzy mojej, kiedykolwiek opuszczę kościół na zawsze, na co tu pijacy, cudzołożnicy, bezwierni, bezbożni i bezwyznaniowi czyhają ciągle, oczekują i pragną, do czego im i inni zamiejscowi dopomagają, tylko inszemi źródłami sobie właściwemi, co gdy nastąpi i przyjdzie do skutku, okażą się też i powyż[ej] zamierzone myśli w swej rzeczywistości zrealizowane ${ }^{85}$.

Po raz kolejny pojawia się wątek ks. Chełmeckiego jako tego, który chciał godzić swojego wikarego z którymś z oponentów. Ks. Knapczyk w dalszej części listu odwołuje się do nieznanego bliżej zdarzenia, w którym miał obrazić Sylwestra Grzybowskiego, kustosza kapituły katedralnej krakowskiej, pełniącego oprócz tego kilka znacznych urzędów w Kościele krakowskim. Nie wiadomo, czego dotyczyła ta sprawa. Ks. Chełmecki zagroził wówczas, że jeśli zielonecki wikary nie przeprosi, wówczas będzie się na niego "gniewać aż do śmierci"86. W kontekście takiego szantażu ks. Knapczyk nie chciał wierzyć w obietnice swego administratora umieszczone we wspomnianym reskrypcie. Rozwiązaniem miałaby być zmiana parafii lub nawet diecezji, jednak za każdym razem zielonecki wikary nie otrzymywał zgody. Rozważania na ten temat kończą się wyrażeniem żalu: „[...] Władza diecezjalna mogłaby mi już była dać przecież jakie beneficjum na wynagrodzenie za tyle krzywd mi wyrządzonych najniegodziwiej, czego świadkiem jest Bóg, a nie dała mi nic i nie da już..." ${ }^{87}$ Pismo to kończy się słowem: „zostaję",

85. AKMKr, APA 355, k. 264.

86. Obietnice więc Wielmożnego Księdza Kanonika Administratora nie wspomogą mię już wtedy więcej, bo pomny na to, co mi Clarissimus Dominus raczył oświadczyć w Krakowie, kiedy szło o to, abym przeprosił x Kanonika Grzybowskiego, iż sie na mnie gniewać będzie aż do śmierci co mię też wielkim podziwem napełniło wtedy, i dziś mię jeszcze tem więcej dziwi owa obietnica wyczytana w reskrypcie, której nie mogę dać wiary" (AKMKr, APA 355, k. 264).

87. AKMKr, APA 355. 
co mogłoby sugerować, iż ks. Chełmecki dawał wikaremu wybór pomiędzy przeniesieniem a pozostaniem i załagodzeniem sporu ${ }^{88}$.

8 marca 1872 roku ks. Knapczyk wysłał do konsystorza pismo, w którym żalił się na Ślizowskiego, jakoby ten kazał aresztować Franciszka Mleczkę. Jechał on na plebanię po księdza, by ten udał się z wiatykiem do chorej żony Jana Adamczyka, gospodarza bibickiego. Kolejny raz nie obyło się bez wyzwisk i gróźb:

[...] Franciszka Mleczko przyaresztowało czterech fornali za to, że przez pole dworskie jechał, a nie wąwozem, czyli drogą zupełnie śniegiem zadętą, którego pan Ślizowski nie nakazał zawczasu wyrzucić, chociaż ta droga przez jego grunt idzie, mimo tego pastwił się z furmanem, którego mu fornale przystawili do stodoły, mierzył mu pięścią do piersi z aklamacją, że go nożem przebije, a na prośbę jego, aby go też puścił, bo kobieta jest już prawie konająca, odrzekł dziedzic pan Ślizowski: „niech wszyscy wyzdychają" - zagroził mu nawet, iż gdyby się ważył przez podworzec jego z księdzem przejechać, to go zastrzeli, więc ten zagrożony musiał przez „Gliniki" przeprawiać się. "Gliniki" jest to stara włościańska polowa droga, która gdzie lepsza i równiejsza była pan Ślizowski jako wójt kazał zaorać, zasiać i wreszcie za swoją własność ją uznał. Gdy atoli przez te "Gliniki" nigdy przejechać nie można ani w lecie, bo przedstawiają same tylko doły, ani w zimie, bo przez całą zimę zaspami śniegu są zawalone, więc też rzeczony Franciszek Mleczko musiał jechać z księdzem polami, po grudzie, przez miedze i zagony z wielkim trudem pół mili, gdzie ani najmniejszego śladu drogi nie ma. A że i w przeszłym roku nakazał pan Ślizowski aresztować gospodarza, który także z księdzem jechał od chorego przez pole, nie mogąc drogą śniegiem zasypaną przejechać, kazał nawet wykopać rów na drodze, aby mu przez pole nikt nie jeździł, tylko wąwozem, z którego śniegu nie wyrzuca regularnie, gdy są zawieje, przez co droga staje się fatalną, przeto mimo wszelkiej ostrożności użytej ze strony tegoż gospodarza, który ani drogą zadętą jechać, ani też rowu wykopanego wyminąć nie

88. AKMKr, APA 355, k. 264v.

Jan Bulak, Między panem wójtem i plebanem... 
mógł, wywrócił się wóz i przywalił księdza jadącego z wiatykiem do chorego. Takie wypadki bez wątpienia dłużej lekceważonemi być nie mogą.

W zakończeniu swojego pisma ks. Knapczyk prosi, by konsystorz zwrócił się do Ślizowskiego z prośbą o umożliwienie przejazdu do Bibic, dokąd ksiądz jeździł nauczać i udzielać sakramentów chorym ${ }^{89}$. Spór dotyczył zatem spraw związanych z prawem własności do gruntu. Po miesiącu (3 IV) konsystorz nakazał rozstrzygnąć tę sprawę ks. Janowi Pietrzykowskiemu, plebanowi mogilskiemu, który pełnił także posługę radcy konsystorza. Zapowiedziano przesłuchanie wikarego oraz dziedzica ${ }^{90}$.

Szybciej niż konsystorz zareagowała jednak rada powiatowa, której wiceprezes 22 marca wniósł prośbę, by wikary "nie dawał powodu do podobnych nieporozumień i pobudek naczelnika gminy Zielonki, przeciw któremu wydział powiatowy nie dostrzegł przewinień w innych rzeczach jego urzędowania dotyczących"91. W końcu jednak i ona odstąpiła rozpatrzenie sprawy plebanowi mogilskiemu ${ }^{92}$. Przesłuchanie obu stron miało się odbyć dopiero 18 września 1872 roku w kancelarii parafialnej w Zielonkach. Kamil Ślizowski nań nie przybył, wobec czego ks. Pietrzykowski przesłuchał wyłącznie ks. Knapczyka w sprawie zarzutów stawianych mu przez dziedzica we wrześniu 1871 roku. Wikary stwierdził wówczas, że "skargi te i zażalenia są całkiem bezzasadne", a na osiem punktów oskarżeń przygotuje odpowiedź później, gdyż wówczas był „złożony słabością"93. Prawdopodobnie nie przygotował jej nigdy.

Przed wrześniowym przesłuchaniem, 4 lipca 1872 roku, ks. Knapczyk wystosował pismo do konsystorza, w którym piętnował naruszenie gruntów plebańskich przez Ślizowskiego i młynarza Józefa Miniewskiego (wypasanie bydła i przywłaszczenie gruntów plebańskich). Ten długi list był bardzo szczegółowy, pełen odwołań do dat i numerów działek, co podkreśla

89. "[...] urząd parafialny ma zaszczyt upraszać uprzejmie Prześwietny Konsystorz o wyjednanie u władzy właściwej tego, aby przynajmniej przez «Gliniki» miał ksiądz wolny bezpieczny i dogodny przejazd do Bibic, gdy w celu pełnienia obowiązków swego najwyższego powołania urzędownie tam się udaje, bo przecież to być nie może, aby jadąc z Najświętszym Sakramentem do chorych musiał przeprawiać się przez zagony, bruzdy, miedze i rowy" (AKMKr, APA 355, k. 272).

90. AKMKr, APA 355, k. 289, 295, 297.

91. AKMKr, APA 355, k. 292.

92. AKMKr, APA 355, k. 294.

93. AKMKr, APA 355, k. 290. Zob. także k. 336, 340, 344, 346. 
skrupulatną zawziętość wikarego, tym bardziej że wikariusz podpierał się alkoholizmem świadków powołanych przez drugą stronę sporu ${ }^{94}$. Sprawa została przekazana ekspozyturze Prokuratorii Skarbu w Krakowie ${ }^{95}$. Nie wiemy, na ile ks. Knapczyk poczuwał się do odpowiedzialności za użytkowane ziemie, a na ile chciał dokuczyć Ślizowskiemu:

[...] Mając już te dokumenta w pogotowiu przed kilku dniami z wielkim trudem i kosztem zebrane wypada tylko pp. Ślizowskiemu i Miniewskiemu wytoczyć proces o oddanie napowrót plebańskiego pastwiska, należącego do całości kościelnego majątku, z którego, jako kapłan miejscowy i dzierżawca gruntu plebańskiego, ani jednej skiby nikomu ustąpić nie mogę bez odpowiedzialności ${ }^{96}$.

W tym samym piśmie wikary informował, iż zachorował na „ból nogi" (potem amputowanej) który w dużym stopniu utrudniał mu chodzenie, oraz że Ślizowski wytoczył mu proces o rzekomo nielegalne postawienie siedmiu tam na rzece przy gruntach plebańskich ${ }^{97}$. W argumentacji nie było zatem odwołań do kwestii dyscypliny kościelnej.

Sprawa ta prawdopodobnie nie miała swojego rozstrzygnięcia, ponieważ omawiane akta parafialne nie zawierają żadnego protokołu ani też pisma, które byłoby poświęcone tej kwestii. Na piśmie z kwietnia 1872 roku znajduje się dopisana notatka, iż ks. Pietrzykowski nie dokończył procesu z powodu śmierci ks. Knapczyka, która nastąpiła półtora roku później. To kolejny dowód na opieszałość krakowskiego konsystorza ${ }^{98}$.

Tuż przed odejściem z parafii ks. Knapczyk (po raz ostatni w swoim kłótliwym życiu) wytoczył proces ks. Janowi Chełmeckiemu o niewypłacenie mu pieniędzy za posługę w Zielonkach ${ }^{99}$. Sprawa była badana przez dziekana bolechowickiego oraz dziekana dekanatu miejskiego, do którego należała kolegiata św. Anny. Znamienne, że także w tej kwestii konsystorz zwlekał z przeprowadzeniem dochodzenia, co zdenerwowało umierającego

94. AKMKr, APA 355, k. 316-319. Zob. także k. 334.

95. AKMKr, APA 355, k. 322, 324.

96. AKMKr, APA 355, k. 334.

97. Zob. AKMKr, APA 355, k. 340, 342, 347.

98. AKMKr, APA 355, k. 296.

99. Zob. AKMKr, APA 355, k. 264, 351, 353, 354v, 355-357, 358-362, 363, 364, 366-367, $368,369-373,374-375,378-379$. 
ks. Knapczyka. W piśmie skierowanym do konsystorza na miesiąc przed śmiercią (6 IX 1873) groził, iż jeśli władza nie przyzna mu pieniędzy, będzie musiał

[...] podawać do gazet, jakie krzywdy, niesprawiedliwość i traktowania czynili mu przełożeni od początku pobytu mego [ks. Knapczyka - JB] w Liszkach ${ }^{100}$ aż do uwolnienia od obowiązków parafialnych w Zielonkach, a będzie podawał tylko to, co jest najczystszą prawdą i nie będzie to wprawdzie ani dla duchowieństwa chlubą, ale niech osądzi publiczność, kto ma słuszność, gdyż inne środki już mu nie pozostają, aby odebrać to, co mu się należy a z grosza pożyczonego nadal niepodobna mu żyć na barłogu ${ }^{101}$.

Prawdopodobnie w ostatnich dniach życia relacje z władzą duchowną stały się dlań całkowicie obojętne. Na kilka dni przed śmiercią (4 X 1873) przesłuchiwany przez dziekana, czy podtrzymuje swoje zarzuty wobec ks. Chełmeckiego, odpowiedział w charakterystyczny dla siebie sposób:

[...] Dni mojego życia są już policzone, niezadługo mam stanąć przed sądem sprawiedliwego Boga, nie chciałbym tam przyjść z kłamstwem na ustach, które zabija duszę człowieka, ale pragnę, abym oczyszczony stanął przed sprawiedliwością boską, dlatego jeszcze raz powtarzam, że mi sumienie nic nie wyrzuca, abym w rzeczonej skardze jakie kłamstwo popełnił. JX Chełmecki nie robił ze mną żadnych układów ani ustnych, ani tym bardziej pisemnych, dlatego nie może mieć żadnej wymówki, a moje żądania w skardze do Prześwietnego Konsystorza przeze mnie wniesionej wymienione są prawne i słuszne i gotów jestem na poparcie tychże uroczystą wykonać przysięgę, jeżeli Wysoka Władza Diecezjalna pozwoli i rozkaże. Na tem kończąc, upraszam najpokorniej [...] aby wszelkie tłumaczenie się i wybiegi JX Chełmeckiego raczyła uważać i osądzić jako fałszywe i nieważne, a zarazem upraszam, by Wysoka Władza Diecezjalna zmusiła JX Chełmeckiego do spiesznego wypłacenia mojej słusznej należytości ${ }^{102}$.

100. Był to jego pierwszy wikariat (1854-1855).

101. AKMKr, APA 355, k. 366.

102. AKMKr, APA 355, k. 374v-375. 
Pod zeznaniem tym nie mógł już się podpisać, gdyż „tak był osłabionym, iż pióra w palcach utrzymać nie mógł"103. Konsystorz nie dał jednak wiary przedśmiertnemu zeznaniu ks. Knapczyka i spór rozsądził na korzyść ks. Chełmeckiego, co umacnia nasze przekonanie o braku autorytetu i nieprawdziwości zeznań byłego wikarego zieloneckiego ${ }^{104}$. Ks. Knapczyk prawdopodobnie nie dowiedział się o tym werdykcie, gdyż zmarł 15 października 1873 roku, dzień przed planowanym doręczeniem mu pisma. Niedługo potem, w wieku 50 lat, umarł Kamil Ślizowski (7 VIII 1874) ${ }^{105}$, który przed śmiercią powrócił do Kościoła. Jego ostatnia spowiedź i zaopatrzenie sakramentami musiały odbyć się za zgodą konsystorza. Następca ks. Knapczyka, Feliks Dasiewicz - jak sam pisał - chciał wykorzystać ten akt do sprowadzenia całej rodziny Ślizowskich do Kościoła ${ }^{106}$.

Pamięć o tym dziedzicu Marszowca żyła długo w parafii Zielonki. W 1878 roku Piotr Kwieciński, podczas opisywania Marszowca w parafialnej kronice, podał, iż jest on własnością sukcesorów Kamila Ślizowskiego, "[...] smutnej pamięci z wielu względów w parafii człowieka"107. Trzydzieści lat po pobiciu ks. Knapczyka ówczesny proboszcz Zielonek zanotował w kronice, iż żona Ślizowskiego „[...] umarła [...] w kilka godzin po wyjeździe z pogrzebu brata swojego, który czynnie znieważył ks. Wojciecha Knapczyka wikariusza w Zielonkach"108. Po śmierci męża nadal dzierżawiła karczmę. Była raczej osobą pracowitą i pełną dobrych intencji, gdyż dokonała przeniesienia budynku karczmy z dotychczasowego miejsca, czyli placu naprzeciwko drzwi wejściowych do kościoła ${ }^{109}$. Drugi samodzielny proboszcz zielonecki Jan Michalik wystawił jej pozytywne świadectwo pośmiertne, choć „była przyczyną wielu złego i gorszyła innych parafian" (co zapewne odnosiło się do apostazji męża), to jednak pod koniec życia przyjmowała sakramenty i „choć kilka razy do roku przecież przyjeżdżała na nabożeństwo do kościoła". Wezwany w nocy proboszcz nie zdążył już dotrzeć

103. AKMKr, APA 355, k. 374.

104. AKMKr, APA 355, k. 378.

105. Pogrzeb odbył się 9 VIII. W księdze zmarłych odnotowano pełną tytulaturę: „Magnificus Dominus Camillus Ślizowski heres praediorum sic dictorum Marszowiec et Rozdziałowskie, natus Cracoviae". Jako przyczynę śmierci podano: „infirmitas (carbunculus)" (APZ, Liber defunctorum 1872-1885). Por. W. Gwizdała, Nad Białucha, dz. cyt., s. 16-17.

106. AKMKr, APA 355, k. 415.

107. APZ, Kronika parafialna, t. 1, s. 14.

108. APZ, Historyja i spis papierów wartościowych;... APZ, Kronika parafialna, t. 1, s. 84.

109. APZ, Kronika parafialna, t. 1, s. 20-21. 
do chorej. Zmarła 21 grudnia 1898 roku $^{110}$. Z sukcesorem Bolesławem Ślizowskim kolejni księża zieloneccy żyli już w zgodzie ${ }^{111}$. Potomkowie energicznego wójta mieszkali na Marszowcu do końca I wojny światowej, po czym wydzierżawili majątek i przenieśli się do Krakowa ${ }^{12}$. Po ponad stu latach od opisywanych wydarzeń autor niewydanych dotąd dziejów Zielonek, Władysław Gwizdała, wspominał, iż w pamięci mieszkańców Ślizowski był „szanowanym przez wieś Starym Ślizowskim"113. Zaznaczył przy tym, iż nie wie, dlaczego ks. Kwieciński miał o nim opinię człowieka "smutnej pamięci"114. Pamiętał jednak o antagonizmach dworsko-plebańskich, choć nie dotarł do ich przyczyny: „[...] Kamil Ślizowski [...] był również przewodniczącym miejscowej rady szkolnej, lecz wskutek jakichś zatargów z wikarym $^{115}$ ks. Knapczykiem zrezygnował z tej funkcji"116.

\section{Zakończenie}

Konflikty między dworem na Marszowcu a plebanią w Zielonkach przebiegały w sposób dramatyczny i takie też miały skutki: znieważenie kapłana, apostazja Kamila Ślizowskiego oraz zgorszenie parafian. Księża Adam Kwiatkowski i Wojciech Knapczyk odchodzili z parafii w złości, a ją samą uważali za pełną ludzi złych i niewdzięcznych. Sami jednak byli temu winni, gdyż ich trudny charakter i - prawdopodobnie - rozgoryczenie z powodu niemożliwości osiągnięcia wyższego stanowiska w sytuacji, gdy dobiegali 60 lat, nie pomagały w spokojnej egzystencji w parafii. O tym, że księża byli ludźmi konfliktowymi, świadczy także to, iż swoje spory prowadzili często latami i z kilkoma antagonistami naraz. Pomimo tego iż wielokrotnie mieli rację (np. ks. Kwiatkowski odmawiając pogrzebu), zachowywali się w sposób, który odpychał wiernych, co dostrzegała władza duchowna.

Dokumenty zachowane w Archiwum Kurii Metropolitalnej w Krakowie nie pozwalają na wyczerpujący i chronologiczny opis sporów toczonych między plebanią a dworem w Zielonkach, dają jednak obraz charakterów postaci i naświetlają tło konfliktów. W latach 60. i 70. XIX wieku parafia ta była w bardzo złej sytuacji: zaniedbany kościół nie interesował

110. APZ, Kronika parafialna, t. 1, s. 84 (tam mylnie: 1899).

111. Zob. APZ, Kronika parafialna, t. 2, passim.

112. W. Gwizdała, Nad Białucha, dz. cyt., s. 20.

113. W. Gwizdała, Nad Białucha, dz. cyt., s. 16.

114. W. Gwizdała, Nad Białucha, dz. cyt., s. 16.

115. W oryginale błędnie: proboszczem.

116. W. Gwizdała, Nad Białucha, dz. cyt., s. 16. 
rezydujących w Krakowie proboszczów w stopniu większym niż płynące z niego dochody. Przebywający na miejscu księża Kwiatkowski i Knapczyk byli ludźmi porywczymi i nieżyczliwymi. Wszyscy liczyli na rozstrzygnięcie konfliktu przez biskupa administratora Gałeckiego, jednak w jego decyzjach należy się dopatrzeć nadmiernego zwlekania. Ówczesny kolator, właściciel dworu na Marszowcu Kamil Ślizowski, nie był słuchany przez wikariuszy i władzę duchowną, stracił więc zaufanie do Kościoła jako instytucji.

Istotne są również cezury czasowe. Omówione w tej pracy konflikty toczyły się w latach 1866-1873, tymczasem już po śmierci proboszcza kolegiaty św. Anny ks. Feliksa Sosnowskiego (1871) Namiestnictwo we Lwowie wyszło z inicjatywą rozłączenia Zielonek i kolegiaty. Po kilku latach starań i dyskusji Senatu Uniwersytetu Jagiellońskiego udało się przeprowadzić i dokończyć separację w latach 1877-1878, kiedy to Zielonki stały się samodzielną parafią i proboszcz stale rezydował przy kościele. Bardzo prawdopodobne, że właśnie opisywane w tej pracy konflikty, które z racji odwoływania się do instancji świeckich były znane nie tylko w sferach kościelnych, również na to wpłynęły.

Reasumując, spory między Kamilem Ślizowskim a konfliktowymi wikarymi Zielonek doprowadzały do zgorszenia wiernych. Winnym w tej sprawie był jednak przede wszystkim krakowski konsystorz, który nie reagował stanowczo i nie stosował wszystkich możliwych środków zmierzających do załagodzenia sporu. Nadmierne odwlekanie rozpatrywania spraw oraz narażanie się na oskarżenia o brak zainteresowania i groźby szumu medialnego z pewnością nie przysparzały autorytetu, a tylko kolejnym dowodem na słabość krakowskiego Kościoła w okresie administracji bpa Antoniego Gałeckiego. 


\section{Bibliografia}

Źródła archiwalne

Archiwum Kurii Metropolitalnej w Krakowie (AKMKr)

Protokół czynności Konsystorza Illnego, 1861, b. sygn.

Akta parafialne (APA)

Akta parafii w Morawicy, sygn. APA 204.

Akta parafii Zielonki, sygn. APA 355.

Wizytacje dziekańskie dekanatu Bolechowice

- 1832, 1864, 1865, 1866, 1867, 1869, 1871, b. sygn.

Archiwum Parafii Zielonki (APZ)

Historyja i spis papierów wartościowych, b. sygn. Kronika parafii,

t. 1-2, b. sygn.

Księga zawierająca spis sprawionych rzeczy do kościoła w wsi

Zielonki oraz nakłady wyłożone na reparacją budynków

plebańskich, b. sygn.

Księgi metrykalne, b. sygn.

Źródła drukowane

Elenchus Venerabilis Cleri tam Saecularis quam Regularis Partis Dioecesis

Cracoviensis Imperio Caesareo-Austriaco in Civilibus Subjectae

et Scholarum in Eadem Existentium Anno Salutis..., Kraków

1839-1888.

Monumenta Poloniae Historica, t. 2, opr. A. Bielowski, Lwów 1872.

\section{Opracowania}

J. Bulak, Duchowieństwo parafii Zielonki (1795-1918), w: XLV Międzynarodowe Seminarium Kół Naukowych "Koła Naukowe - Szkoła Twórczego Działania", t. 1, red. M. Gryglik, i in., Olsztyn 2016, s. 45-49, https://msknolsztyn.files.wordpress. com/2016/og/tom-1-sekcja-humanistyczna-sekcja-teologicznokanonistyczno-familiologiczna.pdf (dostęp: 20.03.2017). 
Corpus studiosorum Universitatis Iagellonicae 1850/51-1917/18, t. 3, red. K. Stopka, aut.: M. Barcik, A. Cieślak, D. Grodowska-Kulińska, U. Perkowska, M. Żukowski, Kraków 2009.

W. Gwizdała, Nad Białucha, 1983 (maszynopis w posiadaniu Biblioteki Publicznej w Zielonkach).

K. Kamieński, "Okropne dzieje przyniósł nam czas". Duchowieństwo diecezji tarnowskiej wobec wydarzeń 1846 roku, Tarnów 2015.

B. Kumor, Ustrój i organizacja Kościoła polskiego w okresie niewoli narodowej (1772-1918), Kraków 1980.

M. Łuczewski, Odwieczny naród: Polak i katolik w Żmiącej, Toruń 2012.

J. M. Małecki, W dobie autonomii galicyjskiej (1866-1918), w: Dzieje Krakowa. Kraków w latach 1796-1918, Kraków-Wrocław 1985.

K. Morawski, Historia Uniwersytetu Jagiellońskiego. Średnie wieki i odrodzenie, t. 2, Kraków 1900.

J. Szczepaniak, M. Hałaburda, Katalog alumnów seminarium na Stradomiu (1801-19oo), Kraków 2006.

J. Urban, Diecezja krakowska w XIX w., w: Kościół krakowski w tysiacleciu, Kraków 2000, s. 304-383.

W. Urban, Wieś podkrakowska w dobie nowożytnej. (Dzieje Bibic w latach 1475-1918), Kielce-Kraków 1976.

M. Wyżga, W tej pięknej ziemi. Gmina Zielonki od średniowiecza do czasów współczesnych, Zielonki 2009. 


\title{
Abstrakt
}

\author{
Jan Bulak \\ Między panem wójtem i plebanem... Konflikt wójtowsko-plebański \\ w latach 6o. i 7o. XIX wieku w podkrakowskiej wsi
}

\section{Słowa kluczowe:}

a) imienne (imiona i nazwiska): Jan Chełmecki, Antoni Gałecki, Wojciech Knapczyk, Adam Kwiatkowski, Kamil Ślizowski.

b) rzeczowe: kolegiata św. Anny, konflikt, parafia, dwór.

c) geograficzne:

dekanat bolechowicki, diecezja krakowska, Marszowiec, Zielonki.
Artykuł ma na celu przybliżenie konfliktu, który rozegrał się w latach 60. i 70. XIX wieku w parafii Zielonki pomiędzy dziedzicem dworu Marszowiec a w jej wikariuszami. Sprawa nie tylko toczyła się w podkrakowskiej wsi, ale także na wokandzie krakowskiego konsystorza biskupiego za pośrednictwem skarg i donosów. W artykule zostały zaprezentowane wyniki badania przyczyn sporu, jego przebieg, rozstrzygnięcie oraz konsekwencje, które musiały ponieść obie strony. Praca jest także przyczynkiem do badań oddziaływania posługi administratora apostolskiego ks. bpa Antoniego Gałeckiego na duchowieństwo i wiernych w pomniejszych parafiach. 


\section{Abstract}

Jan Bulak

Between the commune chief and the priest... The conflict between the commune chief and priests in the 1860 s and 1870 s in a village near Krakow

The article intends to outline the conflict between the squire of the Marszowiec estate and the curates of the Zielonki parish near Krakow in the 1860 s and $1870 \mathrm{~s}$. Not only did the situation take place in the village, but related complaints and denunciations were also investigated by the Krakow Bishops' Consistory. The article presents the findings of an investigation of the causes of the dispute, its course, settlement and consequences for both parties. The study is also a contribution to the research on the impact of the service of administrator apostolic Rev. Bishop Antoni Gałecki on clergy and the faithful in smaller parishes.

\section{Keywords:}

St. Anne's

Collegiate Church, conflict, parish, court, Bolechowice decanate, Krakow diocese. 
